\title{
Developing a change model for peer worker interventions in mental health services: a qualitative research study - CORRIGENDUM
}

\section{S. Gillard, S. L. Gibson, J. Holley and M. Lucock}

doi: 10.1017/S2045796014000407, Published by Cambridge University Press, $3^{\text {rd }}$ July 2014.

Key words: Change model, mental health research, peer support, qualitative research, corrigendum.

The article by Gillard et al (2014) contained an error in the affiliation list. The correct affiliation list is republished here.

S. Gillard ${ }^{1}$, S.L. Gibson ${ }^{1}$, J. Holley ${ }^{1}$ and M. Lucock $^{2}$

${ }^{1}$ Institute of Population Health Research, St George's, University of London, London, UK

${ }^{2}$ University of Huddersfield, Huddersfield, UK

\section{Reference}

Gillard S, Gibson SL, Holley J and Lucock M. Developing a change model for peer worker interventions in mental health services: a qualitative research study. Epidemiology and Psychiatric Sciences. First published online: $3^{\text {rd }}$ July 2014, doi:10.1017/ S2045796014000407 